\title{
Amino acid and peptide absorption after proximal small intestinal resection in the rat $^{1}$
}

\author{
A. B. GARRIDO, JR. ${ }^{2}$, H. J. FREEMAN ${ }^{3}$, Y. C. CHUNG, AND Y. S. KIM 4 \\ From the Gastrointestinal Research Laboratory, Veteran's Administration Hospital, University of California \\ School of Medicine, San Francisco, California, 94143, USA
}

SUMMARY In experimental animals with massive proximal intestinal resection, in vivo ileal absorption of an amino acid mixture containing L-leucine and glycine as well as two different dipeptides, L-leucyl-glycine and glycyl-L-leucine, were compared. Both amino acid and dipeptide absorption were markedly enhanced in the ileal segments. However, the absorption rates from the two perfused dipeptides differed. L-leucine absorption from L-leucyl-glycine was much greater than from glycylL-leucine. Brush border amino-peptidase activities after resection were also increased but dissociation between absorption and hydrolytic activity occurred. This study indicates that certain dipeptides are handled differently by adapting ileal segments. Furthermore, the changes observed probably reflect mucosal cellular hyperplasia occurring in association with intestinal adaptation.

Amino acids are absorbed by different transport mechanisms from the intestinal lumen depending upon whether they are present in free form or as peptides (Silk, 1974; Matthews, 1975; Matthews and Adibi, 1976). Some, but not all, amino acids are more efficiently absorbed from peptides than free amino acid mixtures (Adibi and Phillips, 1968; Craft et al., 1968; Matthews, 1977). Furthermore, peptide transport appears to be less disturbed compared with amino acid transport in some small intestinal disorders (Adibi et al., 1974; Silk et al., 1974b; Adibi, 1976).

After extensive proximal resection, a profound structural and functional change occurs in residual ileum (Nygaard, 1967; Dowling and Booth, 1967; Dowling and Gleeson, 1973; Dowling, 1974). Structurally, increased numbers of ileal epithelial cells are associated with an increase in villus size (Dowling and Gleeson, 1973). Functionally, various hydrolytic enzymes, including sucrase and peptide

${ }^{1}$ Supported by US Public Health Service Grant AM-17938. ${ }^{2}$ A.B.G. is a recipient of a research grant from Fundãcao de Amparo à Pesquisa do Estado (FAPE), São Paulo, Brazil. ${ }^{3}$ H.J.F. is a recipient of a Medical Research Council Research Fellowship, Ottawa, Ontario, Canada.

'Address for reprint requests: Y.S.K., Gastrointestinal Research Laboratory (151M2), V.A. Hospital, 4150 Clement Street, San Francisco, CA, 94121, USA.

Received for publication 16 August 1978 hydrolase (McCarthy and Kim, 1973) as well as the transport of glucose (Dowling and Booth, 1967; Dowling, 1974), are increased in the residual ileal segment. However, no apparent increase in enzyme activities occurs when expressed on the basis of mucosal DNA content (McCarthy and Kim, 1973). This probably reflects epithelial cell hyperplasia with greater numbers of less differentiated enterocytes (Gleeson et al., 1972; Dowling and Gleeson, 1973; McCarthy and Kim, 1973). Whether similar changes occur in amino acid and peptide transport after small bowel resection has not yet been examined.

After massive loss of small intestinal absorptive surface, long-term survival has been documented (Mallinson and Merivale, 1973). Treatment in this situation may include oral administration of free amino acid mixtures as elemental diets (Thompson et al., 1969). Alternatively, small peptides, rather than more costly and more hyperosmotic free amino acid mixtures (Silk et al., 1976a; Silk, 1977), might also be administered in the short bowel syndrome. However, the relative efficiency of absorption of amino acids and peptides in this disorder must first be clarified.

This investigation was undertaken, therefore, to examine residual ileal absorption of the amino acid, L-leucine, and two dipeptides, L-leucyl-glycine and glycyl-L-leucine, after massive proximal small intestinal resection in experimental animals. 
Methods

\section{ANIMALS AND DIET}

Female Wistar rats (Simonsen Laboratories, Inc., Gilroy, California), of the same age and weighing 180 to $200 \mathrm{~g}$, were used for this investigation. Water was supplied ad libitum at all times. Animals were randomly selected from the group for surgery and did not differ significantly in terms of weight from controls. Before surgery, animals were fasted overnight for 12 hours. Sucrose $(5 \%$ weight per volume) was added to the drinking water of all rats for the first 48 hours after surgery. Thereafter, rats were maintained on laboratory chow pellets (Ralston, Purina, St Louis, Mo.).

\section{OPERATION}

Animals for resection were anaesthetised with diethyl-ether. At a point $5 \mathrm{~cm}$ distal to the duodenojejunal transition, 60 to $70 \mathrm{~cm}$ (mean $\pm \mathrm{SEM}$, $65.5 \pm 0.48 \mathrm{~cm}$ ) of small bowel was resected, particular care being taken to preserve an adequate blood supply to the remaining bowel. Measurements were made with the small intestine hung under constant tension with a $10 \mathrm{~g}$ weight. End-to-end enteroanastomosis was then carried out by the technique of Lambert (Lambert, 1965). Before closure of the abdominal wall, $1.0 \mathrm{ml}$ of a solution containing streptomycin $10 \mathrm{mg} / \mathrm{ml}$ and penicillin $10000 \mathrm{U} / \mathrm{ml}$ (Pacific Biologicals, Berkeley, California) was given intraperitoneally.

\section{PERFUSION TECHNIQUE}

Two groups of five animals each were used as paired controls for the two groups of animals with resection. Immediately before perfusion, mean weight ( \pm SEM) of all controls was $263.6 \pm 2.06 \mathrm{~g}$ (two week controls, $248 \cdot 2 \pm 7 \cdot 44$; five week controls, $272 \cdot 4 \pm 5 \cdot 60$ ), while resected rats had mean weights ( \pm SEM) of $236.0 \pm 5.52 \mathrm{~g}$ at two weeks (five animals) after surgery and $253.8 \pm 3.17 \mathrm{~g}$ at five weeks (eight animals). Unfasted animals were used for all perfusion experiments because fasting reduces mucosal brush border peptide hydrolase activity (Kim et al., 1973). Perfusion of each control group was done on the day before the resected group. As results between control groups were not statistically different, they were pooled and presented as one group in the results.

Animals were lightly anaesthetised with diethylether and maintained with subcutaneous pentobarbital ( $5 \mathrm{mg} / 100 \mathrm{~g}$ body weight). A tracheostomy was carried out to aid respiration. The peritoneal cavity was opened in the mid-line, and a segment of residual rat ileum measuring approximately 20 $\mathrm{cm}$ (mean $21.3 \pm 0.67 \mathrm{~cm}$ ) was prepared in all animals $5 \mathrm{~cm}$ proximal to the caecum. Each loop was rinsed with iso-osmotic sodium chloride maintained at $37^{\circ} \mathrm{C}$ and cannulated proximally and distally with polyethylene catheters secured with silk ligatures. After returning the intestine to the peritoneal cavity, the test solution, maintained at $37^{\circ} \mathrm{C}$ in water bath, was infused through the proximal catheter at $19 \mathrm{ml} / \mathrm{h}$ using a Harvard infusion pump (Model 2681, Millis, Mass.). After 30 minutes to attain a steady state, two 10 minute collections were made into plastic tubes positioned in a mixture of dry ice and ethanol to prevent further hydrolysis of test peptides by intraluminal peptide hydrolases. All solutions were perfused through the same loop in a single animal. At the end of the perfusion period, the loop was cleared, refilled with the next test solution, and the sequence of the equilibration and collection was repeated. The sequence of perfusing test solutions was always randomised (Silk et al., 1976b).

After collection of intestinal contents, the frozen samples were stored at $-20^{\circ} \mathrm{C}$ for later analysis. After the perfusion in each animal, the ileal segment was removed, length measured under a constant $10 \mathrm{~g}$ weight, and the mucosa scraped from the intestinal wall and weighed. Scrapings were immediately homogenised in cold normal saline over ice with a Polytron (Kinematica GMBH, Lucerne, Switzerland) and sonicated.

\section{PERFUSION SOLUTIONS}

L-leucine, glycine, L-leucyl-glycine, and glycyl-Lleucine were obtained from Sigma Chemical Co., St Louis, Mo. ${ }^{14} \mathrm{C}$-polyethylene-glycol ( $\left.{ }^{14} \mathrm{C}-\mathrm{PEG}\right)$ was obtained from New England Nuclear, Worcester, Mass. Solutions consisting of $10 \mathrm{mmol}$ L-leucine plus $10 \mathrm{mmol}$ glycine, $10 \mathrm{mmol} \mathrm{L}$-leucylglycine, and $10 \mathrm{mmol}$ glycyl-L-leucine dissolved in $0.9 \%$ normal saline were prepared immediately before perfusion. To each perfusion solution, $0.5 \%$ of nonabsorbable marker polyethylene-glycol labelled with $1.0 \mu \mathrm{Ci}{ }^{14} \mathrm{C}-\mathrm{PEG}$ was added to correct for volume changes. The $\mathrm{pH}$ of all solutions was adjusted to $\mathrm{pH} 7 \cdot 0$ by titration with sodium hydroxide just before perfusion.

\section{ASSAY METHODS}

Aliquots of the samples collected during perfusion of the dipeptide solutions as well as aliquots of the original solutions were hydrolysed in sealed ampoules with equivolume $6 \mathrm{~N}$ hydrochloric acid for 21 hours at $110^{\circ} \mathrm{C}$ and neutralised with $3 \mathrm{~N}$ sodium hydroxide. Aliquots of samples from both the perfused dipeptide and the free amino acid mixture along with a standard $1 \mathrm{mM}$ L-leucine solution were then appropriately diluted, prepared in dupli- 
cate, and incubated in a shaking water bath at $37^{\circ} \mathrm{C}$ for 20 minutes with L-amino acid oxidase reagent (Heizer et al., 1972; Nicholson and Kim, 1975). This reagent was prepared by mixing $10 \mathrm{mg} \mathrm{L}$-amino acid oxidase (Calbiochem, Los Angeles, Calif.), $1 \mathrm{mg}$ horseradish peroxidase (Sigma Chemical Co., St Louis, Mo.), $5 \mathrm{mg}$ o-dianisidine (Sigma Chemical Co., St Louis, Mo.) in $50 \mathrm{ml}$ of $50 \mathrm{mM}$ Tris buffer, $\mathrm{pH} \mathrm{8.0.} \mathrm{The} \mathrm{reaction} \mathrm{was} \mathrm{then} \mathrm{stopped} \mathrm{with} 50 \%$ sulphuric acid and tubes assayed colorimetrically for free L-leucine at $530 \mathrm{~nm}$. The ${ }^{14} \mathrm{C}$-PEG content of test solutions and intestinal contents was measured by a previously validated method (Silk et al., 1974a; 1976b). Quench correction was made by external standardisation. CPMs were converted to DPMs with a computer programme (Beckman Instruments, Inc., Fullerton, California).

Peptide hydrolase activity in scrapings from the ileal segment against the substrates L-leucylglycine and glycyl-L-leucine, as well as control incubations with enzyme alone or substrate alone, were perfomed as previously described using 0.5 mmol p-hydroxymercuribenzoate in the reaction mixture (Nicholson and Kim, 1975). Protein was determined by the method of Lowry (Lowry et al., 1951) and DNA was measured fluorometrically (Kissane and Robins, 1958; Hinegardner, 1971).

\section{CALCULATIONS}

The absorption rate or net rate of disappearance of the amino acid L-leucine during the perfusion was calculated using the formula:

$$
L D R=\left(L_{t}-L_{1} \frac{C i}{C o}\right) R
$$

where LDR is the net rate of leucine disappearance $(\mu \mathrm{mol} / \mathrm{ml}), L_{t}$ is the to al concentration of L-leucine in the test solution $(\mu \mathrm{mol} / \mathrm{ml}), \mathrm{L}_{1}$ is the concentration of L-leucine in the aspirated intestinal contents $(\mu \mathrm{mol} / \mathrm{ml}), \mathrm{Ci}$ is the radioactivity of ${ }^{14} \mathrm{C}-\mathrm{PEG}$ in the test solution $(\mathrm{dpm} / \mathrm{ml})$, Co is the radioactivity of ${ }^{14} \mathrm{C}$-PEG in the collected intestinal contents $(\mathrm{dpm} / \mathrm{ml})$, and $\mathbf{R}$ is the rate of infusion of test solution $(19 \mathrm{ml} / \mathrm{h})$.

The rate of appearance of free L-leucine during intestinal perfusion experiments with test solutions containing peptide (LAR) was calculated using the formula:

$$
L A R=\left(L f \frac{C i}{C o}\right) R
$$

where LAR is the net rate of free L-leucine appearance $(\mu \mathrm{mol} / \mathrm{h})$ and $\mathrm{Lf}$ is the concentration of free L-leucine in intestinal contents collected during the peptide perfusion $(\mu \mathrm{mol} / \mathrm{ml})$. Results of these perfusion studies were expressed per $20 \mathrm{~cm}$ segment of ileum and per mg of ileal mucosal DNA content. The statistical difference in net rates of L-leucine disappearance and the rate of appearance of free L-leucine during perfusion experiments with test solutions containing peptides was calculated using Student's $t$ test.

\section{Results}

\section{TISSUE PARAMETERS}

Table 1 summarises the parameters for the ileal mucosal scrapings corrected to $20 \mathrm{~cm}$ segment length for all animals studied. Mucosal weight, protein, and DNA content reached maximal values in animals studied two weeks after proximal enterectomy. At five weeks, the values were lower but did not differ significantly from animals examined after two weeks. For each tissue parameter examined at both two and five weeks after resection, the values obtained were highly significant $(P<0.001)$ compared with controls. Furthermore, the increase observed was approximately parallel for all tissue parameters. However, the greatest increase was seen in mucosal DNA content.

Table 1 Ileal mucosal tissue parameters in control and resected animals

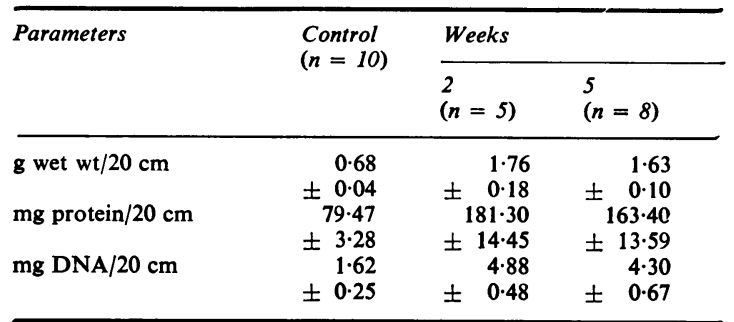

Values represent mean $\pm S E M$. All values in resected animals at two and five weeks were significant $(P<0.001)$ compared with controls.

\section{ABSORPTION STUDIES}

In Fig. 1 , in vivo ileal segmental absorption rates of L-leucine from the perfused amino acid mixture and the equivalent dipeptide solutions are shown. In this study, no statistical difference for L-leucine absorption rates between the free amino acid mixture and L-leucyl-glycine was observed in control animals. However, L-leucine absorption from glycyl-L-leucine was significantly less $(P<0.05)$ compared with absorption from either the free amino acid mixture or L-leucyl-glycine.

Compared with control animals, segmental absorption of L-leucine from all perfused test solutions was increased after resection. Absorption rates from the free amino acid mixture and one 


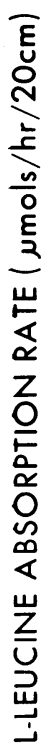

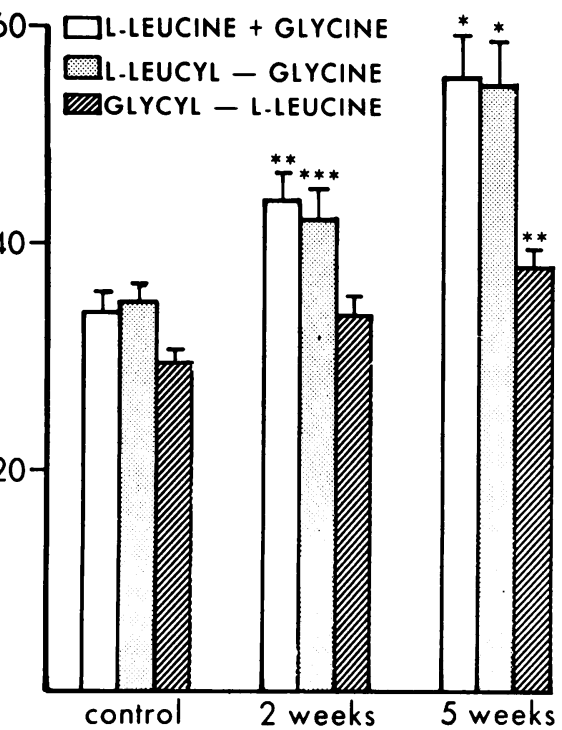

Fig. 1 Ileal absorption rates of $\mathrm{L}$-leucine (mean $\pm S E M)$ from perfused $10 \mathrm{mmol}$ L-leucine and $10 \mathrm{mmol}$ glycine, $10 \mathrm{mmol} \mathrm{L}-l e u c y l-g l y c i n e$, and $10 \mathrm{mmol}$ glycyl$\mathrm{L}$-leucine solutions two and five weeks after proximal resection. $\mathrm{P}(\mathrm{t}$ test versus control animals) as follows: ${ }^{*} \mathrm{P}<0.001 ;{ }^{* *} \mathrm{P}<0.005 ;{ }^{* * *} \mathrm{P}<0.01$

dipeptide, L-leucyl-glycine, were similar, reaching significance both at two weeks and five weeks. Furthermore, absorption from both the freeaminoacid mixture and L-leucyl-glycine increased significantly even between two and five weeks $(P<0.02)$. Glycyl-L-leucine, however, behaved differently. Statistical significance from controls for L-leucine absorption rate was achieved only after five weeks. At five weeks L-leucine absorption was also significantly greater than values from two week animals $(P<0.05)$. Finally, at five weeks, the increase observed for L-leucine absorption from perfused glycyl-L-leucine $(24 \%)$ was not as great as the increase from the free amino acid mixture $(70 \%)$ or the other dipeptide, L-leucyl-glycine $(49 \%)$.

Although the segmental absorption of L-leucine in residual ileum was increased postoperatively, the absorption rates were generally less after resection when expressed per mg of mucosal DNA, as seen in Fig. 2. This reduction was most evident two weeks after surgery. Between two and five weeks, however, absorption rates increased for each substrate when expressed per mg mucosal DNA content. Significance was achieved for both the free amino acid mixture and L-leucyl-glycine $(P<0.05)$, but not glycyl-L-leucine

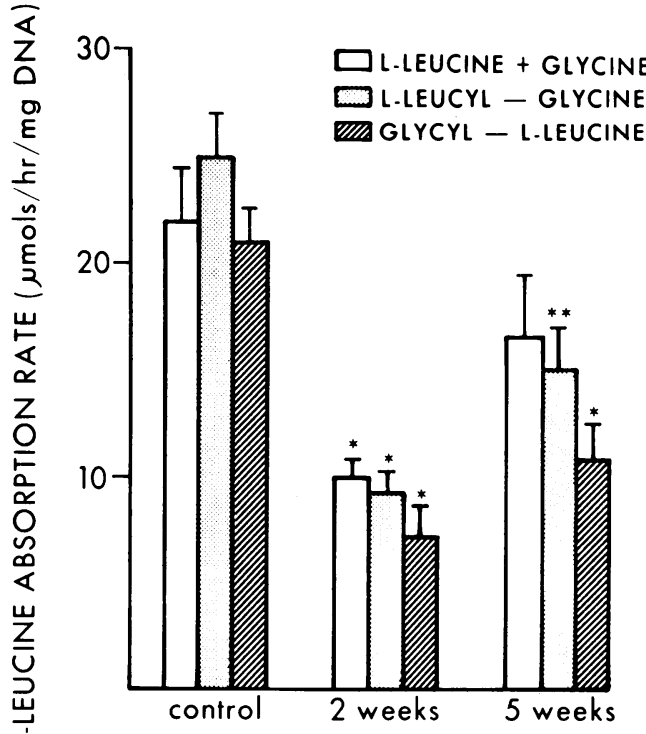

Fig. 2 Ileal absorption rates of $\mathrm{L}$-leucine (mean \pm SEM) from perfused $10 \mathrm{mmol} \mathrm{L}-l e u c i n e$ and $10 \mathrm{mmol}$ glycine, $10 \mathrm{mmol} \mathrm{L}-$ leucyl-glycine, and $10 \mathrm{mmol}$ glycyl-L-leucine solutions two and five weeks after proximal resection expressed per mg of mucosal DNA content. $\mathrm{P}$ ( $\mathrm{t}$ test versus control animals) as follows: ${ }^{*} \mathrm{P}<0.001$; ${ }^{* *} \mathrm{P}<0.0005$.

\section{DIPEPTIDE DIGESTION STUDIES}

Figure 3 shows the appearance rates of free L-leucine calculated from samples collected during perfusion of the dipeptides, L-leucyl-glycine and glycyl-Lleucine. When expressed per $20 \mathrm{~cm}$ ileal segment, a marked increase at both two and five weeks was observed (Fig. 3A). This change was greater at five weeks compared with three weeks for both dipeptides. The L-leucine appearance rate was significantly higher at five weeks for L-leucyl-glycine compared with glycyl-L-leucine $(P<0.005)$. No difference was observed in appearance rates between the two peptides in control animals or two weeks after resection. When expressed per mg of mucosal DNA (Fig. 3B), however, the L-leucine appearance rate was decreased at two weeks and then increased to values higher than controls at five weeks. However, statistical significance was achieved only with L-leucyl-glycine.

Postoperatively, a marked increase in segmental brush border peptidase activity was observed two weeks after resection for both L-leucyl-glycine and glycyl-L-leucine (Table 2). Peptidase activities remained high at five weeks compared with controls. However, no statistical difference was observed between two and five weeks for activity against either 

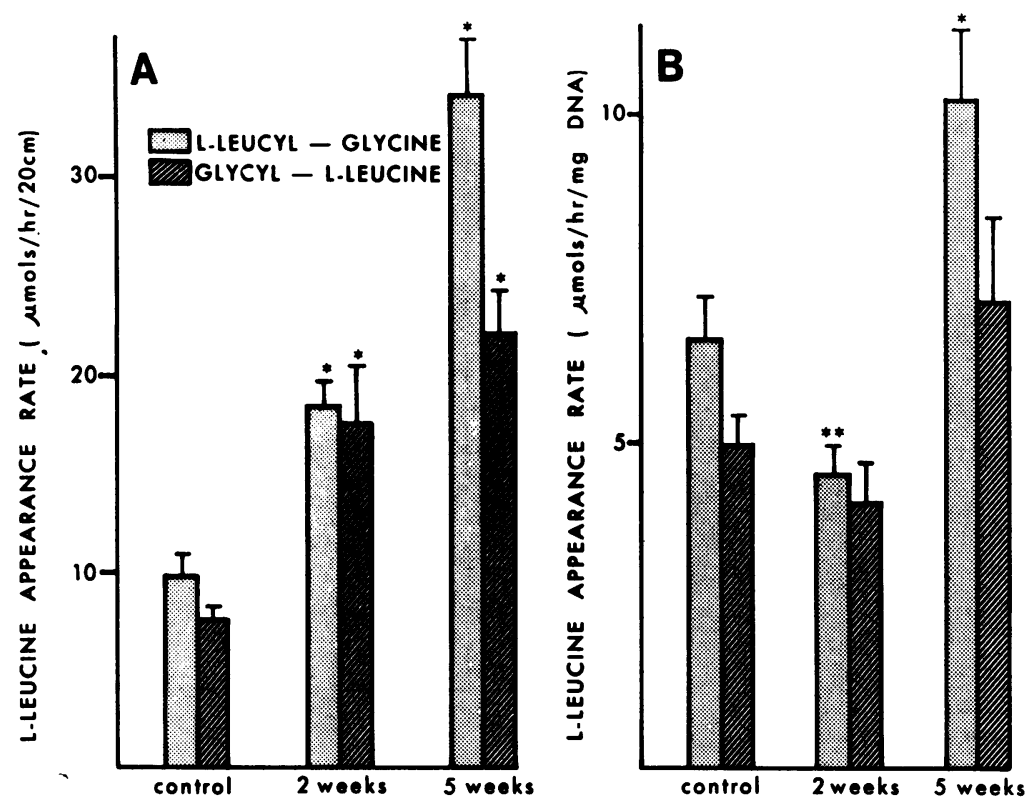

Fig. 3 L-leucine appearance rates (mean $\pm S E M$ ) per 20 cm ileal segment $(A)$ and per mg mucosal DNA (B) during perfusion of $10 \mathrm{mmol}$ L-leucyl-glycine and $10 \mathrm{mmol}$ glycyl-L-leucine solutions at two and five weeks after resection compared to control animals $\mathbf{P}(\mathrm{t}$ test versus controls as follows: ${ }^{*} \mathrm{P}<0.001 ;{ }^{* *} \mathrm{P}<0.05$.

Table 2 Ileal brush border aminopeptidase activities in control and resected animals

\begin{tabular}{|c|c|c|c|}
\hline \multirow[t]{3}{*}{ Substrate } & \multicolumn{3}{|c|}{ Aminopeptidase activity } \\
\hline & \multirow{2}{*}{$\begin{array}{l}\text { Control } \\
(n=10)\end{array}$} & \multicolumn{2}{|l|}{ Weeks } \\
\hline & & $\begin{array}{l}2 \\
(n=5)\end{array}$ & $\begin{array}{l}5 \\
(n=8)\end{array}$ \\
\hline $\begin{array}{l}\text { L-leucyl-glycine } \\
\text { Glycyl-L-leucine }\end{array}$ & $\begin{array}{l}3.25 \pm 0.31 \\
1.35 \pm 0.17\end{array}$ & $\begin{array}{c}\text { (units } / 20 \mathrm{~cm}) \\
15.08 \pm 4.33^{*} \\
5.53 \pm 1.24^{*} \\
\text { (units } / \mathrm{mg} \text { DNA) }\end{array}$ & $\begin{array}{r}11.25 \pm 2.71 \dagger \\
4.84 \pm 0.93\end{array}$ \\
\hline $\begin{array}{l}\text { L-leucyl-glycine } \\
\text { Glycyl-L-leucine }\end{array}$ & $\begin{array}{l}2.01 \pm 0.18 \\
0.83 \pm 0.09\end{array}$ & $\begin{array}{l}3.09 \pm 0.86 \\
1.13 \pm 0.12\end{array}$ & $\begin{array}{l}2.62 \pm 0.31 \\
1.12 \pm 0.10\end{array}$ \\
\hline
\end{tabular}

Values represent mean \pm SEM expressed in standard international units. One unit represents $\mu$ mols of L-leucine released per minute. All values in resected animals at two and five weeks were significant $\left({ }^{*} P<0.001, \dagger_{P}<0.005\right)$ compared with controls.

substrate. When expressed per mg mucosal DNA, values were slightly higher at both two and five weeks, but no statistical difference for either peptide substrate was achieved. In both controls and resected animals, L-leucyl-glycine brush border peptidase activity per cell was two to five times higher than glycyl-L-leucine activity.

\section{Discussion}

In animals with proximal small intestinal resection, ileal mucosal weight, protein and DNA content were greater compared with control animals. Maximal values, observed in this study, occurred two weeks after surgery. Of the three tissue parameters examined, mucosal DNA was increased to the greatest extent at both two and five weeks. This pattern of change in tissue parameters possibly reflects the predominance of cellular hyperplasia in residual ileal mucosa after massive proximal enterectomy. This agrees with previous observations regarding adaptive changes in tissue parameters after resection (Porus, 1965; Dowling and Booth, 1967; Weser and Hernandez, 1971; Dowling and Gleeson, 1973).

In control animals, segmental L-leucine absorption from glycyl-L-leucine was significantly less than absorption from L-leucyl-glycine as well as from the free amino acid mixture (Fig. 1). It was previously observed that intestinal transport of several glycine-containing dipeptides (L-alanyl-glycine vs glycyl-1-alanine, Silk et al., 1973; L-prolyl-glycine vs glycyl-L-proline, Lane et al., 1975) differs in the rates of glycine absorption. This could be explained in part by the hypothesis that dipeptides containing glycine at the amino-terminus (such as glycyl-Lleucine) are poorly hydrolysed by a brush border peptidase (Fujita et al., 1972). Instead, these dipeptides probably undergo an alternative mode of uptake, being absorbed primarily intact into the intestinal mucosal cell (Matthews, 1975). On the other hand, L-leucyl-glycine may use both modes of transport-that is, superficial hydrolysis followed by absorption of free amino acids or intact absorption to be later hydrolysed into constituent amino acids by intracellular peptide hydrolases. 
Segmental ileal absorption of L-leucine from the free amino acid mixture and both dipeptide solutions was significantly greater after resection. The adaptive mechanism for these increments in segmental peptide absorption may be due to increased superficial hydrolysis of peptides followed by increased free amino acid transport, increased intact peptide transport alone, or both. Our data indicate that both transport and hydrolysis are important. Although indirect, the evidence provided by this study suggests that increased transport may be more important. First, segmental L-leucine absorption from the free amino acid mixture is increased at two weeks and continues to rise at five weeks. Alterations in amino acid transport are not known to be dependent upon changes in mucosal peptidase activity. Secondly, a dissociation occurs between absorption and aminopeptidase activities after resection. For L-leucylglycine, the absorption rate is further increased after two weeks. However, peptidase activity does not change during the same time period. For glycyl-Lleucine, hydrolytic activity increases while the absorption rate remains unchanged at two weeks. Between two and five weeks, however, peptidase activity remains unchanged as the absorption increment becomes highly significant. These dissociations between hydrolytic activity and transport suggest that adaptive changes in transport occur independently of changes in hydrolysis.

Whether these changes in transport and hydrolysis are due to a change in the epithelial cell itself, or to an increase in epithelial cell number is not clear. While hyperplasia certainly occurs, the reduced cellular absorption observed, as well as lack of change in cellular brush border activity in resected animals compared with controls, may relate to a relatively greater number of less functionally mature epithelial cells (Loran and Althausen, 1959; Nakayama and Weser, 1971). Mucosal DNA possibly represents only a crude index of total numbers of functionally mature epithelial cells. It is not certain, therefore, whether the increase in cellular absorption between two and five weeks is actually due to an adaptive change in these epithelial cells.

The postoperative increment in absorption from the free amino acid mixture and L-leucyl-glycine was similar at two and five weeks. However, the increase in absorption from glycyl-L-leucine was substantially less than the two other test solutions. This is probably due to known differences in the behaviour of other glycine-containing peptides. Regardless of the exact mechanism for this difference, these observations indicate that certain dipeptides are also handled differently by adapting ileum.
We are indebted to the Medical Illustrations and Photography Department of the V.A. Hospital as well as to Ms E. Garcia for the typing of the manuscript.

\section{References}

Adibi, S. A. (1976). Intestinal phase of protein assimilation in man. American Journal of Clinical Nutrition, 29, 205-215.

Adibi, S. A. Fogel, M. R., and Agrawal, R. M. (1974). Comparison of free amino acid and dipeptide absorption in the jejunum of sprue patients. Gastroenterology, 67, 586-591.

Adibi, S. A., and Phillips, E. (1968). Evidence for greater absorption of amino acid from peptide than from free form by human intestine. Clinical Research, 16, 446. (Abstract.)

Craft, I. L., Geddes, D., Hyde, C. W., Wise, I. J., and Matthews, D. M. (1968). Absorption and malabsorption of glycine and glycine peptides in man. Gut, 9, 425-437.

Dowling, R. H. (1974). The influence of luminal nutrition on intestinal adaptation after small bowel resection and by-pass. In Intestinal Adaptation, pp. 35-46. Edited by R. H. Dowling and E. O. Riecken. Schauttauer: Stuttgart.

Dowling, R. H., and Booth, C. C. (1967). Structural and functional changes following small intestinal resection in the rat. Clinical Science, 32, 139-149.

Dowling, R. H., and Gleeson, M. H. (1973). Cell turnover following small bowel resection and by-pass. Digestion, 8, 176-190.

Fujita, M., Parsons, D. S., and Wojnarowska, F. (1972). Oligopeptidases of brush border membranes of rat small intestinal mucosal cells. Journal of Physiology (London), 227, 377-394.

Gleeson, M. H., Dowling, R. H., and Peters, T. J. (1972). Biochemical changes in intestinal mucosa after experimental small bowel bypass in the rat. Clinical Science, 43, 743-757.

Heizer, W. D., Kerley, R. L., and Isselbacher, K. J. (1972). Intestinal peptide hydrolases: differences between brush border and cytoplasmic enzymes. Biochimica et Biophysica Acta, 264, 450-461.

Hinegardner, R. T. (1971). An improved fluorometric assay for DNA. Analytical Biochemistry, 39, 197-201.

Kim, Y. S., McCarthy, D. M., Lane, W., and Fong, W. (1973). Alterations in the levels of peptide hydrolases and other enzymes in brush-border and soluble fractions of rat small intestinal mucosa during starvation and refeeding. Biochimica et Biophysica Acta, 321, 262-273.

Kissane, J. M., and Robins, E. (1958). The fluorometric measurement of deoxyribonucleic acid in animal tissues with special reference to the central nervous system. Journal of Biological Chemistry, 233, 184-188.

Lambert, R. (1965). Surgery of the Digestive System in the Rat, pp. 413-419. Thomas: Springfield, Ill.

Lane, A. E., Silk, D. B. A., and Clark, M. L. (1975). Absorption of two proline containing peptides by rat small intestine in vivo. Journal of Physiology, 248, 143-149.

Loran, M. R., and Althausen, T. L. (1959). Transport of vitamin $\mathrm{A}$ in vitro across normal isolated rat intestine and intestine subjected to "partial" resection. American Journal of Physiology, 197, 1333-1336.

Lowry, O. H., Rosebrough, N. J., Farr, A. L., and Randall, R. J. (1951). Protein measurement with the Folin phenol reagent. Journal of Biological Chemistry, 193, 265-275.

Mallinson, C. N., and Merivale, W. H. H. (1973). Survival 
in good health for 21 years after removal of all but eighteen inches of small intestine. Guy's Hospital Reports, 122, 269-298.

Matthews, D. M. (1975). Intestinal absorption of peptides. Physiological Reviews, 55, 537-608.

Matthews, D. M. (1977). Introduction. In Peptide Transport and Hydrolysis, pp. 5-14. Ciba Foundation Symposium 50 (new series). Edited by K. Elliott and M. O'Connor. Elsevier: Amsterdam.

Matthews, D. M., and Adibi, S. A. (1976). Peptide absorption. Gastroenterology, 71, 151-161.

McCarthy, D. M., and Kim, Y. S. (1973). Changes in sucrase, enterokinase, and peptide hydrolase after intestinal resection. Journal of Clinical Investigation, 52, 942-951.

Nakayama, H., and Weser, E. (1971). Increase in intestinal pentose phosphate pathway after small bowel resection in the rat. Clinical Research, 19, 400. (Abstract.)

Nicholson, J. A., and Kim, Y.S. (1975). A one step L-amino acid oxidase assay for intestinal peptide hydrolase activity. Analytical Biochemistry, 63, 110-117.

Nygaard, K. (1967). Resection of the small intestine in rats. III. Morphological changes in the intestinal tract. Acta Chirurgica Scandinavica, 133, 233-248.

Porus, R. (1965). Epithelial hyperplasia following massive small bowel resection in man. Gastroenterology, 48, 753-757.

Silk, D. B. A. (1974). Peptide absorption in man. Gut, 15, 494-501.

Silk, D. B. A. (1977). Amino acid and peptide absorption in man. In Peptide Transport and Hydrolysis, pp. 15-29.
Ciba Foundation Symposium 50 (new series). Edited by K. Elliott and M. O'Connor. New York, Elsevier: Amsterdam.

Silk, D. B. A., Chung, Y. C., Kim, Y. S., Burger, K., Conley, K., and Spiller, G. A. (1976a). Comparison of oral feeding of peptide and amino acid meals to normal human subjects (Abstract). Gastroenterology, 70, 937.

Silk, D. B. A., Kumar, P. J., Perrett, D., Clark, M. L., and Dawson, A. M. (1974a). Amino acid and peptide absorption in patients with coeliac disease and dermatitis herpetiformis. Gut, 15, 1-8.

Silk, D. B. A., Nicholson, J. A., and Kim, Y. S. (1976b). Relationships between mucosal hydrolysis and transport of two phenylalanine dipeptides. Gut, 17, 870-876.

Silk, D. B. A., Perrett, D., Webb, J. P. W., and Clark, M. L. (1973). Intestinal transport of two dipeptides containing the same two neutral amino acids in man. Clinical Science and Molecular Medicine, 45, 291-299.

Silk, D. B. A., Perrett, D., Webb, J. P. W., and Clark, M. L. (1974b). Absorption of two tripeptides by the human small intestine: a study using a perfusion technique. Clinical Science and Molecular Medicine, 46, 393-402.

Thompson, W. R., Stephens, R. V., Randall, H. T., and Bowen, J. R. (1969). Use of the "space diet" in the management of a patient with extreme short bowel syndrome. American Journal of Surgery, 117, 449-459.

Weser, E., and Hernandez, M. H. (1971). Studies of small bowel adaptation after intestinal resection in the rat. Gastroenterology, 60, 69-75. 